\title{
Analysis of the variations in price of anti-glaucoma eye preparations available in Indian pharmaceutical market
}

\author{
Sonu Kumar ${ }^{1}$, Anupam Kishore ${ }^{2 *}$, Akash Chandra ${ }^{3}$, Uma Shankar Prasad Kesari ${ }^{4}$
}

\author{
${ }^{1}$ Department of Pharmacology, MGM Medical College, Jamshedpur, Jharkhand, India \\ ${ }^{2}$ P.S.M, ${ }^{3}$ Department of Pharmacology, SNMMCH, Dhanbad, Jharkhand, India \\ ${ }^{4}$ Department of Pharmacology, RIMS, Ranchi, Jharkhand, India
}

Received: 01 July 2021

Revised: 28 July 2021

Accepted: 29 July 2021

*Correspondence:

Dr. Anupam Kishore,

Email: anupamkusum@rediffmail.com

Copyright: (C) the author(s), publisher and licensee Medip Academy. This is an open-access article distributed under the terms of the Creative Commons Attribution Non-Commercial License, which permits unrestricted non-commercial use, distribution, and reproduction in any medium, provided the original work is properly cited.

\begin{abstract}
Background: The aim of the study was to analyze the percentage cost variations among different brands of the commonly prescribed anti-glaucoma drugs.

Methods: The maximum and minimum price of each brand of the drug in INR was noted by using CIMS January to April 2018 edition Drug Today April to June 2018 Vol-1. The cost ratio and the percentage cost variation for individual drug brands was calculated. The cost of each eye drop was calculated. At last the cost ratio and percentage cost variation of various brands was compared.

Results: Percentage variation in cost for anti-glaucoma eye preparations marketed in india was found to be eye drop timolol maleate $(0.5 \%)$ of $5 \mathrm{ml}: 263.63$, eye drop dorzolamide $(2 \%)$ of $5 \mathrm{ml}: 9.77$, eye drop pilocarpine $(2 \%)$ of 5 $\mathrm{ml}: 160.40$, eye drop Betaxolol $(0.5 \%)$ of $5 \mathrm{ml}: 56.54$, eye drop Latanoprost $(50 \mathrm{mcg} / \mathrm{ml})$ of $2.5 \mathrm{ml}: 135.88$, eye drop Brimonidine tartarate $(0.15 \%)$ of $5 \mathrm{ml}: 183.9$, eye drop Levobunolol $(5 \mathrm{mg} / \mathrm{ml})$ of $5 \mathrm{ml}: 32.38$.

Conclusions: Glaucoma is the most common ocular disease and eye drops are to be prescribed for prolonged period. If a costly brand is prescribed, the patients have to pay more money unnecessarily for their treatment. The clinicians prescribing these drugs should be aware of these variations in cost to reduce the cost of drug therapy.
\end{abstract}

Keywords: Glaucoma, Percentage cost variation, Cost ratio

\section{INTRODUCTION}

Glaucoma is a chronic progressive optic disorders which result in damage to the optic nerve and vision loss. ${ }^{1}$ The most common type is open-angle glaucoma and less common types is closed-angle glaucoma and normaltension glaucoma. ${ }^{1}$ Open-angle glaucoma develops slowly over time and there is no pain. ${ }^{1}$ Peripheral vision may begin to decrease followed by central vision resulting in blindness if not treated. ${ }^{1}$ Risk factors for glaucoma include increased pressure in the eye, a family history of the condition, and high blood pressure. ${ }^{1}$ Closed-angle glaucoma can present clinical features gradually or suddenly may involve severe eye pain, blurred vision, middilated pupil, redness of the eye, and nausea. ${ }^{2}$ Raised intraocular pressure is essentially due to an increased resistance to the circulation of the aqueous at the pupil or to its drainage through the angle of the anterior chamber. ${ }^{3}$ Normal intraocular pressure is maintained at $10-21 \mathrm{~mm}$ of $\mathrm{Hg} .{ }^{4}$ The diagnosis of glaucoma is made after looking for a combination of clinical signs characteristic change in the optic nerve head, abnormalities in visual field and a rise in intraocular pressure. ${ }^{5}$ The type of glaucoma is determined by the clinical features and the status of anterior chamber 
angle as determined by gonioscopy. ${ }^{6}$ Patients from poor socioeconomic background must have access to the correct drug at the nominal price. ${ }^{7}$ Costly drugs can lead to economic burden which results in decreased compliance or even non-compliance. ${ }^{8}$ Non-compliance leads to incomplete treatment which tends to increased morbidity. There is a gross variation in the cost of different brands of same generic drugs available in Indian market. Increase in the patient medication cost was found to be associated with decrease adherence to prescription medication. ${ }^{9}$ Cost analysis is the study in which comparison of costs of two or more alternative medication is made without regard to outcome. ${ }^{10,11}$ Studies conducted in past show a wide variation in cost of branded and generic versions of same drugs. ${ }^{12,13}$

Hence the present study was conducted to evaluate the cost variation amongst the different brands of proton pump inhibitors available in India.

\section{METHODS}

Price in Indian rupees (INR) of anti-glaucoma eye preparations manufactured by different pharmaceutical companies in India, in the same strength were obtained from Current index of medical specialists (CIMS) January to April 2018 edition and from Drug Today April to June 2018, vol-1 as they are readily available source of drug information and are updated regularly. The maximum and minimum cost of anti-glaucoma eye preparations of different brands was calculated. The cost of drugs were also crosschecked at pharmacy or retail drug store. Difference in the maximum and minimum price of the same drug formulation manufactured by different pharmaceutical companies and percentage variations in prices are calculated.

The cost ratio, calculated as the ratio of the costlier brand to that of the cheapest brand of the same drug, calculated as follows:
Cost ratio $=$ Price of the costliest brand/Price of the least costly brand.

The percentage cost variation of each drug should be calculated as follows:

Percentage cost variation $=($ maximum cost-minimum cost/minimum cost $) \times 100$.

Maximum minimum percentage cost variation \& cost ratio of a particular drug should be noted down.

\section{Inclusion criteria}

Only anti-glaucoma eye preparations should be included. Doses form of Drugs will be only eye drop. Drugs belong to branded manufacturing companies should be included. Eye drops belong to same or different strength but in same quantity should be included.

\section{Exclusion criteria}

Anti-glaucoma eye drops in combinations with other eye drops as are excluded. The drug formulation being manufactured by only one company or being manufactured by different strengths are excluded. Drugs belong to bogus manufacturing companies should be excluded.

\section{RESULTS}

The analysis of data showed a large variation in costs of different brand of anti-glaucoma eye preparations available In Indian market. Percentage variation in cost for proton pump inhibitors marketed in India was found to be eye drop Timolol maleate $(0.5 \%)$ of $5 \mathrm{ml}: 263.63$, eye drop Dorzolamide (2\%) of $5 \mathrm{ml}: 9.77$, eye drop Pilocarpine $(2 \%)$ of $5 \mathrm{ml}: 160.40$, eye drop Betaxolol $(0.5 \%)$ of $5 \mathrm{ml}: 56.54$, eye drop Latanoprost $(50 \mathrm{mcg} / \mathrm{ml})$ of $2.5 \mathrm{ml}: 135.88$, eye drop Brimonidine tartarate $(0.15 \%)$ of $5 \mathrm{ml}: 183.9$, eye drop Levobunolol ( $5 \mathrm{mg} / \mathrm{ml})$ of $5 \mathrm{ml}: 32.38$.

Table 1: Drug costs, cost ratio and percentage cost variation of anti-glaucoma eye preparations available in Indian market.

\begin{tabular}{|c|c|c|c|c|c|c|}
\hline Drug & Dose/Strength & $\begin{array}{l}\text { No of } \\
\text { brands }\end{array}$ & $\begin{array}{l}\text { Maximum Price } \\
\text { [Rs] }\end{array}$ & $\begin{array}{l}\text { Minimum } \\
\text { Price [Rs] }\end{array}$ & Cost ratio & $\begin{array}{l}\text { Percentage cost } \\
\text { variation in cost }\end{array}$ \\
\hline Pilocarpine & $5 \mathrm{ml} / 2 \%$ & 5 & 51.95 & 19.95 & 2.60 & 160.40 \\
\hline $\begin{array}{l}\text { Timolol } \\
\text { maleate }\end{array}$ & $5 \mathrm{ml} / 0.5 \%$ & 15 & 80 & 22 & 3.63 & 263.63 \\
\hline Betaxolol & $5 \mathrm{ml} / 0.5 \%$ & 5 & 37.18 & 23.75 & 1.56 & 56.54 \\
\hline Dorzolamide & $5 \mathrm{ml} / 2 \%$ & 3 & 247 & 225 & 1.09 & 9.77 \\
\hline Latanoprost & $\begin{array}{l}2.5 \mathrm{ml} / 50 \mathrm{mcg} \text { per } \\
\text { Milli litre }\end{array}$ & 9 & 401 & 170 & 2.35 & 135.88 \\
\hline $\begin{array}{l}\text { Brimonidine } \\
\text { tartarate }\end{array}$ & $5 \mathrm{ml} / 0.15 \%$ & 10 & 304 & 107.27 & 2.83 & 183.39 \\
\hline Levobunolol & $\begin{array}{l}5 \mathrm{ml} / 5 \mathrm{mg} \text { per } \\
\text { Milli litre }\end{array}$ & 2 & 135.52 & 102.37 & 1.32 & 32.38 \\
\hline
\end{tabular}


Dorzolamide eye drop shows minimum cost ratio as: 1.09 and minimum percentage cost variation as: 9.77 Timolol maleate eye drop shows maximum cost ratio as: 3.63 and maximum percentage cost variation as: 263.63.

We can prefer those drug who possess cost ratio less than 2 and percentage cost variation less than 100 , so we can prefer Dorzolamide eye drop to patients.

\section{DISCUSSION}

The Indian market there is no system of registration of Medicines. More than one company sells a particular drug under different brand names apart from the innovator company. This situation has led to greater price variation among drugs marketed. These wide variations in the prices of different formulations of the same drug have severe economic implications in India. People in developing countries pay the cost of medicines out-of-pocket. In India, more than $80 \%$ health financing is borne by patients. Patients have to pay more unnecessarily if costly brands are prescribed. Many poor people frequently face a choice between buying medicines or buying food. In India, more than $80 \%$ health financing is borne by patients. ${ }^{12-14}$ The situation becomes more complex due to the presence of number of brands with variety of names and prices. ${ }^{15}$ The price variation assumes significance when the cost ratio exceeds 2 and percentage cost variation exceeds 100. By this fact the above analysis showed that cost ratio and percentage cost variation of Betaxolol $(0.5 \%, 5 \mathrm{ml})$, Dorzolamide $(2 \%, 5 \mathrm{ml})$, and Levobunolol (5 mg per millilitre, $5 \mathrm{ml}$ ) is below 2 and 100, so these drugs do not show significant price variation and these drugs can be prescribed in poor patients. Significant price variation creates economic burden on poor patients. Costs of drugs are controlled by the drug cost control order 2013 (DPCO). ${ }^{16}$ Hence, we need to draw attention to the prices of various drug formulation brands available to reduce the cost of therapy. ${ }^{17}$ The treating physician should be made aware of the cheapest drug available among the various brands so that the patient bears lesser burden of treatment cost. ${ }^{18}$ Similar cost variations was found in cost of Antimalarial drugs available and many other drugs. 18 In India, doctors have less awareness in the cost difference of different brands of the same drug. It is felt that physicians could provide better services and reduce costs of drugs if information about drug prices was readily available.

\section{CONCLUSION}

The above study shows a wide variation in the prices of different brands of anti-glaucoma eye preparations available in Indian market (Table 1). There is a strong need to create awareness about this huge price variation among the general public, health care providers, health care payers, government agencies, policy makers, pharmacists for appropriate intervention to reduce economic burden on patients as well as the healthcare system. Ceiling cost of drugs are fixed by national pharmaceutical pricing authority government of India in accordance with DPCO
2013. Despite this there exists a wide variation of drug costs within one drug with the availability of various brands. The national pharmaceutical pricing authority (NPPA) should act strictly to ensure that the prices of antiglaucoma drugs are brought under control so that all patients irrespective of the economical class should be able to afford these medicines and get treated completely.

Funding: No funding sources

Conflict of interest: None declared

Ethical approval: The study was approved by the Institutional Ethics Committee

\section{REFERENCES}

1. "Facts About Glaucoma'. National Eye Institute. Accessed on 29th March 2016.

2. Mantravadi AV, Vadhar N. "Glaucoma". Primary Care. Saunders (Elsevier). 2015;42(3):437-49.

3. Mishima S, Masuda K, Tamura T. In: Drugs Influencing Aqueous Humor Formation and Drainage Dikstein S (ed): Drugs and Ocular Tissues. International Society for Eye. 1977;128-287.

4. Goel M, Picciani RG, Lee RK, Bhattacharya SK. Aqueous Humor Dynamics: A Review often Ophthalmol J. 2010;4:52-9.

5. Thomas R, Loiblks, Parikh R. Evaluation of a glaucoma patient. Indian $\mathbf{J}$ Ophthalmol. 2011;59(1):S43-52.

6. Smith SD, Singh K, Lin SC, Chen TC, Francis BA et al. Evaluation of the Anterior Chamber Angle in Glaucoma. A Report by the American Academy of Ophthalmology. Ophthalmology. 2013;120:1985-97.

7. Eaddy MT, Cook CL, O’Day K, Burch SP, Cantrell CR. How patients cost-sharing trends affects adherence and outcomes; a literature review: PT. 2012;37:45-55.

8. Ahuja J, Gupta M, Gupta AK, Kohli K. Pharmacoeconomics. Natl Med J India. 2004;17:80-3.

9. Sanchez LS. Pharmacoeconomics: Principles, methods and applications. In: Dipiro JT, Talbert RL, Yee GC.

10. Das SC, Mandal M, Mandal SC. A critical study on a vailability and price variation between different brands:impact on access to medicine. Indian J Pharm Sci. 2007;69(1):160-3.

11. Chawan VS, Gawand K V, Badwane SV. Cost analysis of oral hypolipidemic agents available in India. Int J Basic Pharmacol. 2014:3:954-7.

12. Thomas M. Rational drug use and essential drug concept. In: Parthasarthi G, Hasen NK, editors. A Textbook of Clinical Pharmacy Practice. Orient Longman. 2004;723.

13. Creese A, Kotwani A, Kutzin J, Pillay A. Evaluating pharmaceuticals for Health policy in low and middle income country settings. In: Free mantle N, Hill S, eds. Evaluating pharmaceuticals for Health policy and reimbursement. Blackwell Publication. 2004;227-43.

14. Mahal A, Karan A, Engelgau M. The Economic Implications of Non-communicable Disease for India. 
Washington, DC: World Bank. 2010 http://siteresourses.worldbank.org/HEALTHNUTR ITIONANDPOPULATION/Resourses/281627$1095698140167 /$ Economic Implications of NCD for in dia.pdf. Accessed on $1^{\text {st }}$ May, 2021.

15. Rataboli PV, Garg A. Confusing brand names: nightmare of medical profession. J Postgrad Med. 2005;51:13-6.

16. Drug cost control Order, 2013 Government of India. http://www.nppaindia.nic.in/DPCO2013.pdf. Accessed on 1st May, 2021.

17. Vieira JL, Portal VL, Moriguchi EH. How much do we pay for a benefit? A descriptive cost analysis of the use of statins: The need for a national cost-effectiveness analysis. Arq Bras Cardiol. 2001;76(5):409-18.

18. Kumar L. Cost variation analysis of antimalarial drugs available in India. Int J Res Med Sci. 2017;5(9):40514.

Cite this article as: Kumar S, Kishore A, Chandra A, Kesari USP. Analysis of the variations in price of anti-glaucoma eye preparations available in Indian pharmaceutical market. Int J Basic Clin Pharmacol 2021;10:1110-3. 